\title{
The Connectivity of Nutrient Ratios on The Abundance of Phytoplankton Population In Jakarta Bay
}

\author{
Tumpak Sidabutar ${ }^{1, *}$, Endang S. Srimariana ${ }^{2}$ \\ ${ }^{1}$ Research Centre for Oceanography LIPI. Jl. Pasir Putih 1, Jakarta, Indonesia \\ ${ }^{2}$ Faculty of Fisheries, Bogor Agricultural University, Dramaga. Bogor, Indonesia
}

\begin{abstract}
The frequency of algal bloom's event has been increased in Jakarta Bay, recently. Most of the bloom events were tend to be reoccurred after the rainy season. The research was conducted from 2008 until 2015 to study the linkage of nutrients and the ratios on the growth of the phytoplankton population. Collecting samples were conducted using a canonical plankton net of $20 \mu \mathrm{m}$ mesh size, 125 $\mathrm{cm}$ length and $30 \mathrm{~cm}$ diameter of the opening mouth. The results of the study showed that the concentration of phosphate in the waters ranged from $0.01-12.5 \mu \mathrm{g} / \mathrm{l}$ (average $4.58 \mu \mathrm{g} / \mathrm{l}$ ) and nitrate ranged from $0.01-15.89 \mu \mathrm{g} / \mathrm{l}$ (average $0.72 \mu \mathrm{g} / \mathrm{l}$ ). The $\mathrm{N} / \mathrm{P}$ ratio during the study ranging from 0.2 up to 45.4 . High ratios of nutrients were mostly recorded in 2010 where the overall abundance of phytoplankton is very high. There is a strong correlation of N/P ratio with the community structure or composition of the phytoplankton population. The variability of phytoplankton abundance appears to be related to nutrient ratios of nitrate and phosphate.
\end{abstract}

\section{Introduction}

Nutrient enrichment, mainly nitrogen and phosphor, was considered to be the stimulating factor of phytoplankton growth in the coastal waters such as in Jakarta Bay. Generally, nutrient enrichment as a result of anthropogenic activity occurs in estuaries and coastal waters, such as Jakarta bay, and blooms of phytoplankton are one of the effects of such an accelerated process of nutrient enrichment. Jakarta bay receives a lot of nutrients input from various sources such as agriculture, industries, domestic waste, urban waste, and consequently, resulted in eutrophication. The continuous input of nitrate and phosphate may cause the waters to became too nutrient-rich, which is known as eutrophication $[1,2,3]$.

Jakarta Bay has been classified as a body of water with very high fertility or hyper eutrophication $[4,5]$. The eutrophication and algal blooms have been identified as a major environmental problem in Jakarta bay in the last decades. Increased nitrogen $(\mathrm{N})$ and phosphorus (P) inputs are often considered as the main causes of coastal eutrophication.

*Corresponding author: tumpaksid@gmail.com 
Coastal eutrophication is not a new phenomenon in Jakarta Bay and it is often associated with the occurrence of algal bloom or red tide $[6,7]$.

The growth of the phytoplankton population is highly dependent on the availability of nutrients in the waters, especially phosphates and nitrates. The nitrogen-to-phosphorus ratio $(\mathrm{N}: \mathrm{P})$ has been frequently used as a key indicator in predicting algal biomass and compositions, and its seasonal succession [8,9]. It can also serve as an index that represents the nutrient limitation for algal growth. The atomic ratio, $16 \mathrm{~N}: 1 \mathrm{P}$, which is known as the Redfield ratio, has been used for generally describing the average elemental composition of phytoplankton. Many investigations; however, have shown this ratio to vary considerably, depending on the algal species and surrounding environmental conditions [10], and that optimum nutrient ratios vary interspecifically within the diatoms due to growth competitions. Usually in freshwater phosphorus $(\mathrm{P})$ acts as a limiting factor and nitrogen $(\mathrm{N})$ limiting factors in marine ecosystems [11]. The role of nutrients especially nitrogen and phosphorus as limiting factors for phytoplankton is an important aspect to reduce and regulate eutrophication.

Nutrients enrichment can lead to community changes or succession between populations or species. The availability of nutrients sufficiently will result in total biomass to increase, on the contrary, changes in the nutrient composition may result in changes in species composition. Phosphate and nitrate are nutritional components that play an important role in supporting phytoplankton growth, but excessive nutrients concentration can cause an abnormal explosion of the phytoplankton population. Aquatic disasters such as mass mortality of fish and other living organisms also often occur during the events of algal bloom in these waters.

The relationship between eutrophication and expansion of algal bloom is still relatively unknown, even though in general the eutrophication can affect the explosion of microalgae populations. In some places, the frequency of algal bloom increases due to the increase in nutrient levels, especially phosphate and nitrate [12, 13]. How the eutrophication may stimulate the occurrence of toxic phytoplankton species is still widely unknown and is still under debate until now [14].

The research had been conducted to study the relationship of phytoplankton abundance with the nutrients ratio of nitrogen and phosphate in Jakarta bay. There could be a strong connection of nutrient enrichment due to anthropogenic activities, mainly nitrogen and phosphorus and their ratios with the emergence of harmful algal bloom in this bay.

\section{Materials and methods}

\subsection{Description of location}

The research location is in the waters of Jakarta Bay which is located at coordinates $5^{\circ}$ 53'23.3"- 6 $07^{\prime} 46.9^{\prime \prime}$ South Latitude and coordinates 106 37'10.9"- 107 01'40.8" East Longitude. Map of Jakarta bay and sampling station as shown in Figure 1. Aquatic ecosystems experience problems due to increasing input load of organic material through some rivers which flowing to this bay, urban drainage and also run-off from land during rainfall. Likewise, it is noted that there are frequent aquatic disasters such as mass fish kills and other marine organisms due to the occurrence of bloom events $[6,15]$. 


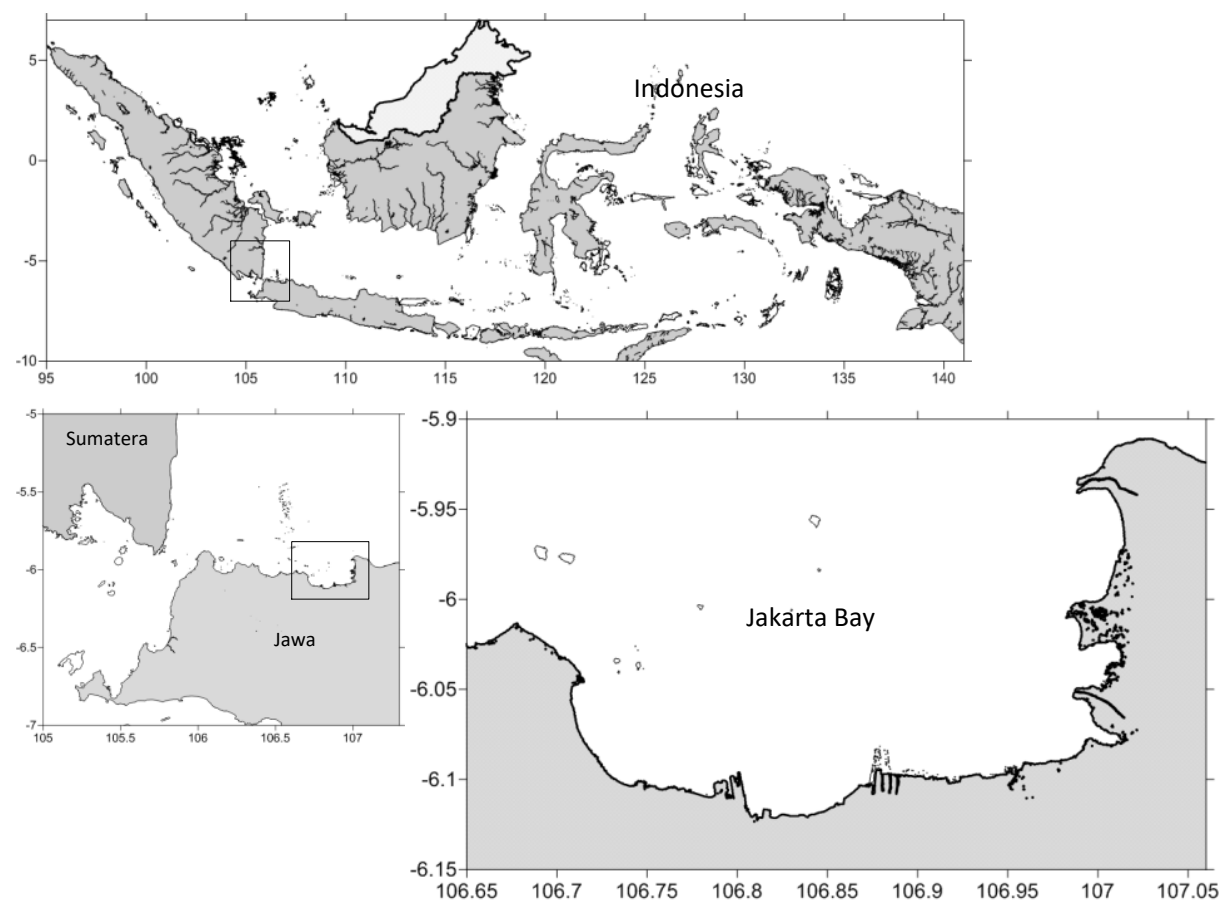

Fig. 1. Map of Indonesia (upper) and the location of Jakarta Bay with 10 sampling stations

\subsection{Study Periode}

This research was carried out and focused in east-monsoon season or dry seasons from 2008 until 2015. The study was conducted in dry season by considering the algal bloom events in the waters usually appeared in the east-monsoon season $[6,16]$. Generally, the season in this region is classified into west-monsoon or rainy season. Between the two seasons, there are transitional seasons I and II. The rainy season occurs from October to March and dry season from April to September. In the rainy season, a lot of organic material enters the waters through sewage discharge, freshwater run-off, rivers flowing into the bay. Therefore, in the rainy season, the nutrients level generally was increased in the waters, mainly phosphate and nitrate and it will fertilize the waters to a certain concentration.

\subsection{Phytoplankton Sampling}

Phytoplankton sampling was carried out using a cone-shaped phytoplankton net which at the end was installed with a pinch to collect concentrates of phytoplankton samples. The pore size or mesh size was $20 \mu \mathrm{m}$, and the net length was around $125 \mathrm{~cm}$ with the opening diameter of the net mouth was $25 \mathrm{~cm}$. At the end of the net, a ballast was installed so that it can be lowered vertically. The sampling was carried out by lowering the phytoplankton net vertically up to a depth of 7-10 $\mathrm{m}$ and then being drawn slowly with a constant from a certain depth to the surface. Phytoplankton samples collected in the bucket were then put into a sample bottle and given preservative. Samples were preserved immediately using acidic Lugol's solution [17]. The preserved phytoplankton samples brought to the laboratory for further quantitative and qualitative analysis under an Olympus inverted microscope (Model IX50-S8F2). Phytoplankton removal was done by Sedgwick-Rafter Counting Cell [14, 18]. 
Quantitatively, the abundance of phytoplankton cells from each phytoplankton genus was calculated. Phytoplankton identification was done based on several taxonomic references $[19,20,21]$. The abundance of phytoplankton cells was calculated according to the procedure described in [17]. The total number of cells of individual species collected at each depth of each station was quantified and the phytoplankton abundance was expressed as the number of cells per cubic volume.

\subsection{Nutrient analysis and oceanographic parameters}

The nutrients in this study were mainly dissolved inorganic nitrogen (DIN), including ammonium nitrogen $\left(\mathrm{NH}_{4}-\mathrm{N}\right)$, nitrate-nitrogen $(\mathrm{NO}-\mathrm{N})$ and nitrite-nitrogen $(\mathrm{NO}-\mathrm{N})$, and dissolved inorganic phosphorus (DIP), including phosphate-phosphorus $\left(\mathrm{PO}_{4}-\mathrm{P}\right)$. The method for analysis of nutrients used in this study was based on the transformation, through a chemical reaction of the substance to be analyzed, to another compound that can be measured colorimetrically within the wavelength range of the visible spectrum. The water sample was filtered with Millipore filter paper pore size $0.45 \mu \mathrm{m}$. The steps followed [22]. The spectrophotometer employed in this study was a Philips PYE Unicam (Model PU8600). As a general rule, all samples were analyzed as soon as possible after collection and especially when the concentration was expected to be low.

Other Oceanographic parameters such as water depth, water temperature, dissolved oxygen, and salinity were measured in situ. The readings of water temperature and dissolved oxygen were taken directly from a YSI Dissolved Oxygen Meter (Model 59) and salinity (in parts per thousand) was measured using an ATAGO Hand Refractometer. The degree of acidity $(\mathrm{pH})$ of seawater is measured by the $\mathrm{pH}$ meter of the TOA model of HM-IK model by dipping the electrode into it.

Climatological data were obtained from a meteorological institution (BMKG) and tidal predictions were obtained from Hydrography and Oceanography Center (Navy Pushidrosal). Climatological data needed include such as (1) rainfall (millimeters), (2) rainy days, (3) air humidity (\%), (4) air temperature $\left({ }^{\circ} \mathrm{C}\right),(5)$ solar irradiation $(\%),(6)$ monthly data on wind speed (Km/hour), and wind direction (degree).

Data analysis was done with the 2010 version of Excel program which was equipped with XLStatistical analysis. The main component analysis (PCA) was used to simplify data, transform data linearly to form a new coordinate system with maximum variance. PCA analysis can associate descriptive roles in quantitative and qualitative constraints. Correspondence analysis (CA) is used to transform data into two dimensions.

\section{Results}

\subsection{Oceanographic characteristics}

Table 1. The averages of oceanographic parameters during the study

\begin{tabular}{ccc}
\hline Oceanographic Parameters & Range & Average \\
\hline Temperature $\left({ }^{\circ} \mathrm{C}\right)$ & $29.72-30.48$ & 29.97 \\
Salinity $(\mathrm{psu})$ & $27.72-30.88$ & 28.98 \\
$\mathrm{pH}$ & $7.68-8.30$ & 8.03 \\
Dissolved Oxygen $(\mathrm{ppm})$ & $2.96-5.17$ & 4.12 \\
\hline
\end{tabular}


The annual average water temperature during the study period was $29.97{ }^{\circ} \mathrm{C}$ with its range from $29.72-30.48^{\circ} \mathrm{C}$. The lowest monthly water temperatures during the study period were $29.37^{\circ} \mathrm{C}$, recorded in May 2008 and the highest was $30.48^{\circ} \mathrm{C}$ recorded in March 2013. The annual average salinity was 28.98 PSU with its range from $27.72-30.88$ PSU. The lowest monthly salinity during the study was 26.41 PSU, occurred in March 2009 and the highest salinity was 30.88 occurred in May 2010. The salinity range was relatively stable with the exception in May 2008 and March 2009 and June 2009 The average dissolved oxygen (DO) ranged from $2.96-4.12 \mathrm{ppm}$. The lowest oxygen was $2.96 \mathrm{ppm}$ recorded in March 2009. It seemed to be unusual during the study. There was no speculation idea regarding to this value. The annual average of $\mathrm{pH}$ was $8.03 \mathrm{ppm}$, ranging from 7.68-8.30. The lowest monthly $\mathrm{pH}$ was 7.68 occur in July 2015 and the highest monthly pH was 8.19 in May 2015. The averages of oceanographic parameters in Jakarta Bay during the study were summarized as seen in Table 1.

There were no extreme values of the oceanographic parameters during the study periods, except the lowest oxygen value recorded in March 2009. Because of the relatively shallow water depth (6-15 meters), as well as flushing by tides and currents, no distinct stratification occurred in Jakarta Bay.

\subsection{Phosphate and nitrate concentration and the ratio}

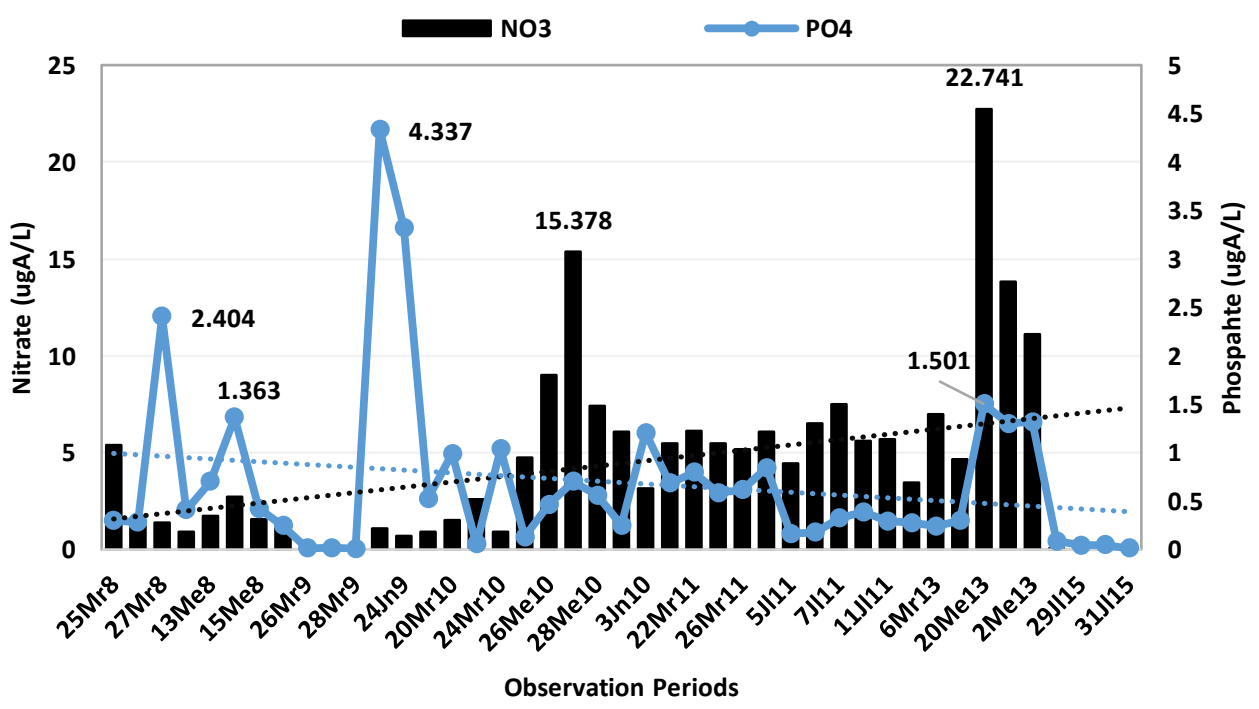

Fig. 2. The fluctuation of phosphate and nitrate concentration during the study 2008-2015.

Figure 2 showed the graph of concentration of phosphate and nitrate during the study periods. The graph showed that phosphate concentration ranging from 0.01-12.5 $\mu \mathrm{g} / \mathrm{L}$ (mean: 4.58 $\mathrm{ug} / \mathrm{L}$ ) and nitrate ranging from $0.01-15.89 \mu \mathrm{g} / \mathrm{L}$ (mean: $0.72 \mathrm{ug} / \mathrm{L}$ ). The lowest concentration of phosphate was recorded in March 2009 and the highest was in June 2009. The lowest concentration of nitrate was recorded in March 2009 and the highest recorded in May 2013. Both phosphate and nitrate concentration during the study periods significantly fluctuated. The average nitrate concentration fluctuated normally from 2008 until 2009, and after that, the concentration increased from 2010 until 2013. The highest peak of nitrate recorded in 2013. The average concentration of nitrate decreasing since 2015, while phosphate, high 
concentration noted from 2008 until 2009, and then increased after 2010 until 2015. The highest peak of phosphate concentration along the study was recorded in 2009 .

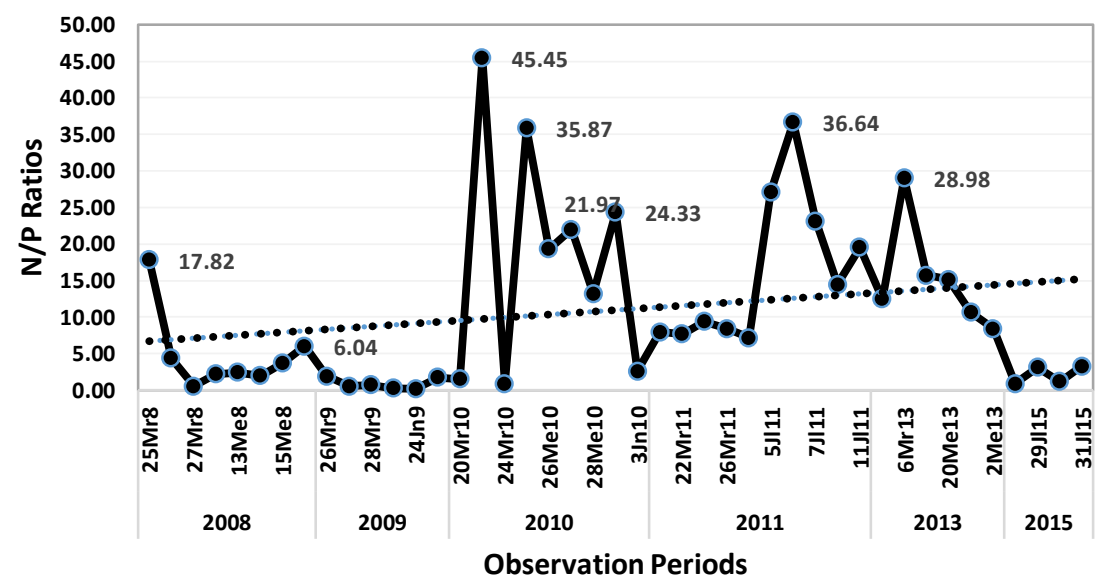

Fig 3. The fluctuation of N/P ratios and its trendline in Jakarta Bay from 2008-2015.

The ratio of phosphate $(\mathrm{P})$ and nitrate $(\mathrm{N})$ during the study period from 2008-2015 as shown in Figure 3. It is seen that the graph of N/P ratio along with the study ranging from 0.2 to 45.4, where the highest ratio was recorded in 2010. The graph of N/P ratio from 2008 until 2009 was decreased, while the graph of N/P ratio from 2010 until 2013 was increased. The N/P ratio values in 2010 seemed higher compared to the others, where the highest value was 45.40. It was shown that nitrate concentration higher than phosphate in the waters during that time. It seemed that nutrient enrichment of $\mathrm{N}$ and $\mathrm{P}$ in this bay was occurring since 2010, onwards.

\subsection{Phytoplankton abundance}

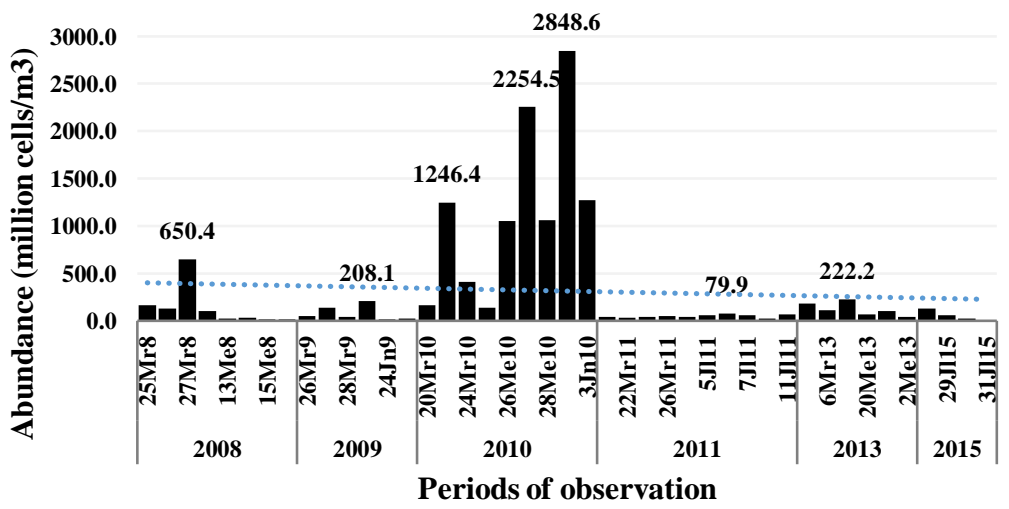

Fig. 4. The abundance of phytoplankton in Jakarta Bay in the study period from $2008-2015$.

The graph of phytoplankton abundance is shown in Figure 4. The abundance of phytoplankton during this study ranging from $21.71 \times 10^{6}$ cells $\mathrm{m}^{-3}$ up to $20.61 \times 10^{8}$ cells.m 3 . The highest abundance of phytoplankton population was mostly observed in the period of 2010 , ranging from $46.6 \times 10^{7}$ cell. $\mathrm{m}^{-3}$ up to $28.49 \times 10^{8}$ cell. $\mathrm{m}^{-3}$. It is interesting to note that 
phytoplankton abundance in 2010 was an unusual occurrence during this study. The number of the population was very contrasted compared to those before and after 2010. It was observed that the highest peaks of the population reached the number of cells of more than $10^{6}$ cells. $\mathrm{m}^{-3}$. When the number of phytoplankton population very dense or reach more than $10^{6}$ cells. $\mathrm{m}^{-3}$, it may cause discoloration in the surface water, due to algal bloom $[23,24]$. Usually, the discolorization of surface water in this bay will appear if the phytoplankton abundance laid between $10^{5}-10^{6}$ cells. $\mathrm{m}^{-3}[6]$.

\section{Discussion}

\subsection{Phytoplankton and nutrient}

Factors that can affect the phytoplankton growth were mainly the availability of nutrients such as phosphates and nitrates in the waters. There is a correlation between the increasing amount of phytoplankton with nutrient availability in the waters [11,25]. Phytoplankton growth in the waters ecosystems basically controlled by three factors such as nutrient availability, light availability, and the response of the algae to nutrients and light [26, 27]. Several hydrological parameters such as temperature, salinity, $\mathrm{pH}$ and dissolved oxygen also play a role in phytoplankton growth. It is clearly seen in this study that the abundance of phytoplankton in Jakarta Bay has a strong relationship with nutrients availability. It was recorded that the abundance of phytoplankton increased very high in 2010, where the number of nutrients, mainly nitrate concentration, increased very high from 2010 until 2013. The high amount of phytoplankton population in 2010 may be indicated that the waters were being eutrophicated or enriched by anthropogenic nutrients which discharged to the bay [28]. The increase of anthropogenic activities in the surrounding areas has consequently increased the nutrients in the environment. The recent exponential growth of the city in terms of both population and urban development may be a contributing factor in the increasing intensity of algal blooms in Jakarta Bay. Similarly, there were reported evidence about the increasing frequency and magnitude of algal bloom events world-wide, and they are linked to eutrophication $[24,29]$.

\subsection{N/P ratios}

The response of the phytoplankton to nutrients is considerably influenced by its physiological state when the nutrients are in short supply. Usually, algae increase their uptake rates for $\mathrm{NH}$ when $\mathrm{N}$ starved and for $\mathrm{PO}_{4}{ }^{3-}$ when $\mathrm{P}$ starved. Redfield (1958) reported atomic ratios of available nitrogen to phosphorus of 15:1 in seawater, depletion of nitrogen and phosphorus in the ratio of 15:1 during phytoplankton growth, and ratios of 16:1 for laboratory analyses of phytoplankton. This ratio was subsequently called the Redfield ratio. It is now agreed that marine phytoplankton growth is limited primarily by nitrogen $[4,33,34]$ indicated that although there is no indication of any normal or optimal nitrogen to phosphorus ratio in algae, values between 5:1 and 15:1 are most commonly encountered and an average ratio of 10:1 is, therefore, a reasonable working value. [8] experimentally determined the optimal N/P ratio for various algal species. Most of the values on their list are within the range 5:1 to 15:1.

Therefore it was estimated that the N/P ratio is highly fluctuating in value and depends on the season. The results showed that phytoplankton abundance increased in tune with an increasing N/P ratio. The ratio of nitrate and phosphate during this study was high in 2010 and 2013, while in 2011 it was relatively low. If the N/P ratio is high, it indicates that Nitrate is a trigger and phosphate is a limiting agent, whereas in 2011 the N/P ratio was relatively low indicating phosphate as a trigger and nitrate as a limiting factor. 


\subsection{Phytoplankton composition}

The phytoplankton population in Jakarta bay during the study consisted of 27 genera of diatoms and 13 genera of dinoflagellates. Entirely, there are 40 genera that make up the phytoplankton population. The diatoms were the dominant group all over the year of the study, but it seems that diatoms were more sensitive than dinoflagellates and other algal groups to the increase in nutrients. Coastal marine waters, particularly embayments and estuaries, are typically more fertile than the open ocean. The urbanization of coastal marine and estuarine areas results in a dramatic increase in population, so that eutrophication by anthropogenic activities such as urban waste and sewage discharge, increasing use of agricultural fertilizers, freshwater run-off, riverine nutrient inputs, coastline construction, tourism, mariculture, etc., are now the major causes in the marine environmental pollution. Many estuaries and coastal waters are eutrophic because of the large amounts of inorganic nutrients (primarily nitrogen and phosphorus) and organic matter they receive from anthropogenic activities. It is a widespread phenomenon in coastal areas and estuaries all around the world.

One explanation for higher diatom abundance and lower abundance of other algal groups is that diatoms are more sensitive to nutrient enrichment than the others. Studies have shown that diatoms have high growth rates under nutrient-rich conditions [12, 30], compared to the generally lower growth rates of dinoflagellates. The higher concentrations of inorganic $\mathrm{N}$ and $\mathrm{P}$ in Junk Bay may result in a higher abundance of diatoms [31]. Unfortunately, there is a lack of long phytoplankton data from this bay and so algal population succession of all species.

\subsection{Nutrients enrichment and phytoplankton growth}

It was recorded that the N/P ratio was higher than 16 in this bay. This indicating that the availability of nitrogen was relatively high, which could trigger phytoplankton growth, while the availability of phosphate was relatively lower (limiting growth). If the N/P ratio is greater than 16, it indicates that there is enough nitrogen as a trigger for the growth of phytoplankton (triggering factor) while phosphate is a limiting factor or P-limited.

The criteria set for the N/P ratio in estuarine or coastal waters are as follows: if the ratio of $\mathrm{N} / \mathrm{P} \leq 5$ then $\mathrm{N}$ is a limiting factor or N-limiting, while if the ratio of N/P between 5-10 is called intermediate. Furthermore, if the $\mathrm{N} / \mathrm{P}$ ratio is $\geq 10$, the limiting factor for growth is phosphate (P-limiting). It appears that there is a link between the N/P ratio and the abundance of phytoplankton. When the N/P ratio is high $(\mathrm{N} / \mathrm{P} \geq 10)$, the abundance of phytoplankton tends to be high. On the contrary, if the N/P ratio is low $(\mathrm{N} / \mathrm{P} \leq 5)$ then the abundance of phytoplankton tends to be low [29, 32]

If the ratio of $\mathrm{N}$ and $\mathrm{P}$ is high or greater than 16 , then the limitation of phytoplankton growth is phosphate (P). Furthermore, if the N/P ratio is low or smaller than 16, then the limiting phytoplankton growth is Nitrogen $(\mathrm{N})$. Besides that, the Redfield ratio can also be used as an indicator of the structure of the phytoplankton community composition $[8,10]$.

\section{Conclusion}

The variability of phytoplankton abundance in Jakarta Bay has a strong connection with the ratio of nutrients, especially nitrates and phosphates. The N/P ratio in Jakarta Bay especially in the east-monsoon season ranging from 0.2 up to 45.5. The abundance of phytoplankton in Jakarta Bay is closely related to the state of eutrophication (mainly $\mathrm{N}$ and $\mathrm{P}$ ), where the bloom occurred when the N/P ratio increase, meaning that nitrate plays a role as triggering factor and phosphate as a limiting factor for the growth of phytoplankton. 


\section{References}

1. D.M. Anderson, P.M. Gilbert, J.M. Burkholder. Harmful algal blooms and eutrophication: Nutrient sources, composition, and consequences. Estuaries 25, 704 726. (2002).

2. S.W. Nixon. Eutrophication and macrosscope. Hydrobiologia 629 : 5-19. (2009)

3. G. M. Hallegraef, D.M. Anderson, and A.D. Cembella. Manual on Harmful marine Microalgae, UNESCO. Paris, France (2008).

4. A. Damar. Effect of enrichment on nutrient dynamics, phytoplankton dynamics and productivity in Indonesian coastal waters: a comparison between Jakarta Bay, Lampung Bay and Semangka Bay. PhD thesis. The Faculty of Mathematics and Nat. Sci. Christian-Albrechts-Univ. Kiel. (2003)

5. Z. Arifin, T. Susana, P. Purwati, R. Muchsin, D. Hindarti, S.H. Riyono, A. Razak, E. Matondang, Salim, \& N. Farida. Ecosystem and productivity of Jakarta Bay and its surrounding. Draft Report of Competitive Research, Indonesian Institute of Sciences, Jakarta (in Indonesian). (2003)

6. S. Wouthuyzen, C.K. Tan, J. Ishizaka, T.P. Hoang Son, R. Varis, S. Tarigan, and A. Sediadi. Monitoring of Algal Blooms and Massive Fish Kill in the Jakarta Bay, Indonesia using Satellite Imageries. Proceed. Symposium of ALOS Data Model. Science Program in Kyoto. (2007)

7. T. Sidabutar. The conditions of plankton in Jakarta Bay: an assessment on the ecosystem of Jakarta Bay. Research Centre for Oceanography, Indonesian Institute of Sciences. Jakarta. (In Indonesian). (2008).

8. I. J. Hodgkiss \& K. C. Ho,. Are changes in N:P ratios in coastal water the key to increased red tide blooms. Hydrobiologia 352: 141-147. (1997)

9. R. Hecky \& P. Kilham. Nutrient limitation of phytoplankton in freshwater and marine environments: a review of recent evidence on the effects of enrichment. Limnol. Oceanogr. 33: 796-822. (1988)

10. R.J. Geider and J. La-Roche. Refield Revisited: Variability of C:N:P in marine microalgae and its biochemical basis. Eur J Phycol 37:1-17 (2002)

11. J. Heisler, P. Glibert, J. Burkholder, D. Anderson, W. Cochlan, W. Dennison, C. Gobler, Q. Dortch, C. Heil, E. Humphries, A. Lewitus, R. Magnien, H. Marshall, K. Sellner, D. Stockwell, D. Stoecker, M. Suddleson. Eutrophication and Harmful Algal Blooms: A Scientific Consensus. Harmful Algae 8, 3-13. (2008).

12. D. Qiu, L. Huang, J. Zhang, S. Lin. Phytoplankton Dynamics in and near the highly eutrophic Pearl River Estuary, South China Sea. Continental Shelf Research 30:177186. (2010).

13. J.H. Lim J.H. \& C.W. Lee. Effects of eutrophication on diatom abundance, biovolume and diversity in tropical coastal waters. Environ. Monit. Assess. 189: 432. (2017)

14. B. Karlson, C. Cusack, E. Bresnan (eds). Microscopic and Molecular Methods for Quantitative Phytoplankton Analysis. Intergovernmental Oceanographic Comission Manuals and Guides (55). UNESCO (2010)

15. Arifin Z. Local Millennium Ecosystem Assessment: Condition and trend of the Greater Jakarta bay Ecosystem. Report submitted to Assistant Deputy for Coastal and Marine Ecosystem, The Ministry of Environment, Republic of Indonesia. 28 p. (2004)

16. T. Sidabutar. Preliminary report on phytoplankton samples from Jakarta Bay in relation to massive fish-kill. Research Centre for Oceanography -LIPI, Jakarta. (2004).

17. A. Sournia. Phytoplankton Manual. Monographs on Oceanographic Methodology. UNESCO, Fontenoy, Paris. (1978).

18. Michael P. Ecological Methods for Field and Laboratory Investigations. McGraw-Hill Publishing Company Limited (1995). 
19. G. E. Newell and R.C. Newell. Marine Plankton. A Practical Guide. Anchor Press, London (1977).

20. I.E. Yamaji. Illustration of the Marine Plankton of Japan. Houkusho. Osaka, Japan (1966).

21. C.R. Thomas. Marine phytoplankton. Academic Press, Inc. San Diego: 262pp. (1993).

22. T.R. Parson, Y. Maita, and C.M. Lalli. Manual of chemical and biological methods for seawater analysis. Pergamon Press, Canada. (1984).

23. G. M. Hallegraeff. A review of harmful algal blooms and their apparent global increase. Phycologia 32: 79-99 (1993).

24. D.M. Anderson. The Ecology and Oceanography of Harmful Algal Blooms. Multidisciplinary Approaches to Research and Management. UNESCO. (2007)

25. M. Strokal \& C. Kroeze. Nitrogen and phosphorus inputs to the Black Sea in 1970-2050. Reg. Environ. Change 13: 179-192 (2013).

26. C.S. Reynolds. The Ecology of Phytoplankton. Cambridge University Press. 535 pp. (2006)

27. C.M. Duarte. Coastal eutrophication research: a new awareness. Hydrobiologia 629: 263-269 (2009).

28. I.M. Suthers and D. Rissik. Plankton: A guide to their ecology and monitoring for water quality. CSIRO Publishing. 256 pp (2009).

29. P.M. Glibert, S. Seitzinger S, C.A. Heil, H.M. Burkholder, M.W. Parrow, L.A. Codispoti, V. Kelly. The role of eutrophication in the global proliferation of Harmful Algal Blooms. Oceanography 18 (2), 198-209 (2005).

30. R.W. Eppley. The growth and culture of diatoms. In Werner, D. (ed.), The Biology of Diatoms. Bot. Monogr. 13: 24-64 (1977).

31. I.J. Hodgkiss and S. Lu. The effects of nutrients and their ratios on phytoplankton abundance in Junk Bay, Hong Kong. Hidrobiologia 512: 215-229 (2004).

32. P.M. Glibert. 2007. Eutrophication and Harmful Algal Blooms: A Complex Global Issue, Examples from the Arabian Seas including Kuwait Bay, and an Introduction to the Global Ecology and Oceanography of Harmful Algal Blooms (GEOHAB) Programme. International Journal of Oceans and Oceanography, 157-169 (2007).

33. A.F. Alimov. Changes in the structure of animal communities accompanying eutrophication and pollution of aquatic ecosystems. Doklady Biological Sciences 433: 249-251 (2010).

34. H. Kim, S. Hwang, J. Shin, K.G. An and C.G. Yoon. Effects of limiting nutrients and $\mathrm{N}: \mathrm{P}$ ratios on the phytoplankton growth in a shallow hypertrophic reservoir. Hydrobiologia 581: 255-267 (2007). 